Avrupa Bilim ve Teknoloji Dergisi

Sayı 18, S. 486-493, Mart-Nisan 2020

(C) Telif hakkı EJOSAT'a aittir

Arastırma Makalesi
European Journal of Science and Technology

No. 18, pp. 486-493, March-April 2020

Copyright (C) 2020 EJOSAT

$\underline{\text { Research Article }}$

\title{
Smart House with Artificial Intelligence
}

\author{
Melek Tomaş ${ }^{1 *}$ Neslihan Dostoğlu ${ }^{2}$ \\ ${ }^{1}$ Akdeniz Üniversitesi, Mimarlık Fakültesi, Mimarlık Bölümü, Antalya, Türkiye (ORCID: 0000-0001-5947-214X) \\ 2 İstanbul Kültür Üniversitesi, Mimarlık Fakültesi, Mimarlık Bölümü, İstanbul, Türkiye
}

(İlk Geliş Tarihi 15 Şubat 2020 ve Kabul Tarihi 9 Mart 2020)

(DOI: $10.31590 /$ ejosat.689634)

ATIF/REFERENCE: Tomaş, M. \& Dostoğlu, N. (2020). Smart House with Artificial Intelligence. Avrupa Bilim ve Teknoloji Dergisi, (18), 486-493.

\begin{abstract}
Technological developments are diversified every day from the early periods of human existence, changing human life more and more. The most intense period of these developments is the IT Revolution. This period has brought processes such as artificial intelligence, electronic commerce and online life. Just as a hundred years ago, electricity transformed everything, and artificial intelligence is expected to transform all industries today.

Technological developments in recent years have also shown itself in the design and production of housing and have begun to change the technical characteristics of the houses that improve the quality of life of the user. The way homes are used has changed, people have become used for their homes for work, entertainment and their families. Sustainable to produce time-appropriate solutions, to save energy and living costs while protecting nature, in short, to improve quality of life, to facilitate life at home, to provide a safer, more comfortable and more costly environment. Smart House" proposal has also emerged in this process.

It's impossible to predict what the future will look like. However, it will show time whether human intelligence will increase or remain in the shadow of artificial intelligence, thanks to smart homes that are becoming widespread by the development of technology. The purpose of this study was analyzed by the SWOT method of smart homes thanks to extensive literature research on smart homes and interviews with smart home experts. This study is expected to make an important contribution to interdisciplinary studies.
\end{abstract}

Anahtar Kelimeler: Smart Home, Artificial Intelligence, Architecture and Technology, Energy Saving, Quality of Life.

\section{Yapay Zekaya Sahip Akıllı Evler}

\section{$\ddot{O} \mathbf{z}$}

Teknolojik gelişmeler insan varlığının ilk dönemlerinden itibaren her geçen gün çeşitlendirilmekte ve insan yaşamını giderek daha fazla değiştirmektedir. Bu gelişmelerin en yoğun yaşandığı dönem Dördüncü Endüstri Devrimi olarakta bilinen Bilişim Devrimi'dir. Bu dönem yapay zeka, elektronik ticaret ve online yaşam gibi süreçleri getirmiştir. Tıpkı yüz yıl önce olduğu gibi, elektrik her şeyi dönüştürmesi gibi yapay zekanın da günümüzde bütün endüstrileri dönüştürmesi beklenmektedir.

Son yıllarda yaşanan teknolojik gelişmeler insan yaşamının her alanında olduğu gibi konut tasarımında ve üretiminde de kendini göstermiş ve konutların kullanıcının yaşam kalitesini artıran teknik özelliklerini değiştirmeye başlamıştır. Evlerin kullanım şekli değişmiş, insanlar evlerini iş, eğlence ve aileleri için kullanır hale gelmiştir. Sürdürülebilir ve zamana uygun çözümler üretmek, teknolojik ürünleri yönetmek ve doğayı korumakla birlikte enerji ve yaşam maliyetinde tasarruf sağlamak, kısacası yaşam kalitesini artırmak için, daha güvenli, daha konforlu ve daha tasarruflu bir ortam sunan sürdürülebilir "Akıllı Ev" önerisi de bu süreçte ortaya çıkmıştır.

Geleceğin nasıl olacă̆ını tahmin etmek mümkün değildir. Ancak, teknolojinin gelişmesi ile yaygınlaşan akıllı evler ile insan zekasının artacağı mı, yoksa yapay zekanın gölgesinde mi kalacağını zaman gösterecektir. Bu çalışmanın amacı, kapsamlı literatür araştırması ve akıllı ev uzmanlarıyla yapılan görüşmeler sonucunda çıkan veriler, SWOT yöntemiyle değerlendirilerek disiplinler arası çalışmalara önemli bir katkı sunması beklenmektedir.

Keywords: Akıllı Ev, Yapay Zeka, Mimarlık ve Teknoloji, Enerji Tasarrufu, Yaşam Kalitesi.

\footnotetext{
* Sorumlu Yazar: Akdeniz Üniversitesi, Mimarlık Fakültesi, Mimarlık Bölümü, Antalya, Türkiye, ORCID: 0000-0001-5947-214X, melektomas07@gmail.com
} 


\section{Introduction}

When researches in the field of science and technology from before history to the present day are examined, two important points are emerging in the development of technology. The first point is that technology is associated with nature because people shape the world of objects, nature, and sometimes even are inspired by nature. The second point is that people need technological materials to survive (Basalla, 2013).

Mechanical production facilities were established in the First Industrial Revolution with the use of water and steam power. In the Second Industrial Revolution, mass production began with the use of electrical energy. In the Third Industrial Revolution, automation production with electronic systems began. In the Fourth Industrial Revolution, the internet of things, the cellular transport system, autonomous interaction and virtualization were developed.

While the first three phases of the Industrial Revolution have promoted mechanization and mass production, the fourth Industrial Revolution, also known as the It Revolution, has brought processes such as economy, electronic commerce, electronic business and online life (Lighted and Kucukvardar, 2016).

The IT Revolution, which emerged in the late twentieth century, has started a whole new era. This period can also be called the digitization of the industry. The It Revolution, also known as Industry 4.0, includes technological advances such as inter-machine communication, internet, automation, artificial intelligence and robotic devices, where things can communicate with each other over the Internet.

The Fourth Industrial Revolution is not just about smart and connected machines and systems, its scope is much wider. From gene sequences to nano-technologies, there are simultaneous advanced breakthrough waves in a number of fields of quantum information processing from renewable energies. What makes the Fourth Industrial Revolution fundamentally different from previous revolutions is the intersecting and intertwining of these technologies in physical, digital and biological fields (Schwab, 2016).

The technologies that stand out with the Fourth Industrial Revolution are cyber physical systems, horizontal vertical integration, internet of things, learning robots, big data, cloud computing, augmented reality, cybersecurity, three-dimensional printers. Groundbreaking robotic history began in the 21 st century. Robots are electromagnetic machines that perform tasks according to predefined instructions. Most robots are equipped with artificial intelligence to make their own decisions (Winston, 2014).

The first smartphone iphone iphone in 2007 was produced in 2010, the first successful tablet computer. In 2018, Sophia, the first artificially intelligent robot, was produced. In the same year, Google designed the driverless smart car project. With the development of technology, people's approach to work, communication and handling day-to-day work have been redefined. A world connected globally has evolved with the emergence of the Internet. Within the scope of the technical, social and cultural changes contained in the industrial revolution, new materials and requirements first had an impact on railways and bridges and then on buildings, and the search for rational and healthy settlements in the globalized world multiplied.

During the Information Revolution, increased use of technology causes differentities in our everyday lifestyle, daily living needs, as well as manifested in residential design and production and to change the technical characteristics of housing Started. To produce time-appropriate solutions, to manage technological products and to protect nature, to save energy and cost of living, in short, to improve the quality of life, The "Smart Home" proposal, which offers a safer, more comfortable and more cost-saving environment that makes life easier, has also become widespread in this process.

In studies on smart home, instead of the concept of smart home to this day; Concepts related to home automation, intelligent structure, building automation system, smart building and integrated home systems have been used. As many different concepts have been used for the name of the smart house to date, various descriptions have been made by many researchers in the smart house to this day (Akdaş, and The Sun, 2015).

The concept of smart home has been described by researcher Lütolf as a home that creates an economical, safe and comfortable environment by combining the different services the user needs in a common communication network (Lütolf, 1992). Smart home, mennicken and friends using computer technologies to increase the comfort of users can be done at home or easier to do things that need to be done, user-sensitive, home it is defined as a technological home that can learn by monitoring the behavior of its residents (Mennicken, Vermeulen, \&huang, 2014).

Aldrich describes the smart house as a home that integrates communication technologies with computers and can offer comfort and security conveniences to home residents (Fernandez, Losada\&Domonte, 2014). Gügül has defined the smart house as a safe, comfortable and energy-saving home that can meet the needs of the residents, make their lives easier, and save energy thanks to the integration of home technologies and home automation (Güğ̈̈l, 2008).

In the 1900s, the invention of small household appliances also led to smart homes developing systems. While the invention of small household appliances is not what we call smart today, it can be seen as a great success for the twentieth century. In 1966 , the kitchen computer was named the first smart device, which was able to store recipes, calculate the amount of the shopping list, turn off and off devices based on home temperature (Hendricks, 2014).

Home automation systems used today in smart house: Smoke sensor, door entrance control, thief alarm system, energy measurement, panic button, irrigation, lighting, off-the-floor heating. The aforementioned home automation systems are added according to the user's needs, improving the quality of life of the person and saving energy. 
In 1950, push button manor was built by Emil Mathias, considered the first smart house. Many devices at home have been automated by setting up various mechanisms. The curtains have many systems such as automatic withdrawal, closing windows when it rains and lights on when pressed with a pitch (Brudbury, 1950).

In 1991, gerontology science used technology to make life easier for older people. One of these new research and technologies is smart homes. Thanks to smart houses, 24 hours of health checks were carried out. Since 2000, information about smart home has become widespread. Smart homes that provide security, energy saving and comfort are built around the world today with an environmentally friendly sustainable approach. Current home automation systems used in smart homes are used with remote control, automatic lights, smart thermostat, text notifications with user interface, mobile and e-mail tools to be able to program and write scenarios and remote cameras can be supervised by the house.

When the development of smart houses has been examined since 1950, it has been observed that these technologies have entered the houses with the advancement of technology. It is increasingly important that the user is becoming more aware of energy, increased security and ensured safety is provided against potential problems at home. In addition, comfort the quality of life is increased by increasing, health checks are carried out, entertainment facilities are offered. The purpose of this study is to make an overview of smart homes.

\section{Smart Home Concept and Smart Home Types}

Given the literature research and developments about smart homes to date, smart home is desired to be defined; With scenarios created according to predetermined need programs of homeowners, which can be managed and programmed with technological devices such as smart homes, remote controls, smartphones or tablets, an unusual in case of a new generation of technological facilities that can notify the user, and most importantly, are environmentally friendly, saving comfort, safety and energy, where users can watch their homes at all times and off the ground, and offer them conveniences in their lives design. In smart homes, home automation systems are determined according to the needs of people living in the house, and the characteristics of each smart house are flexible because they vary according to the user's wishes.

Therefore, the definition of a smart house varies according to its users, because everyone's expectation of a smart house is different. For example, elderly people with disabilities and need care, the expectation of a smart home, health checks can be done and the use of their medicines properly, while the need of a university student who wants to celebrate with relatives at home, the sound of the house to make the space of your smart house fit for purpose with various automation systems such as changing the image of the system, light system and walls. Features of the smart house: Home automation systems, energy and ecology, safety and safety, comfort, health, technology, entertainment and flexibility are summarized below.

\section{1) Home Automation Systems}

Home automation systems used today in smart home are shown in Figure 1. It varies depending on the needs of the person who uses the smart house. Systems used: Smoke sensor, door entrance control, thief alarm system, energy measurement, panic button, irrigation, lighting, floor heating. The aforementioned home automation systems are added according to the user's needs, improving the quality of life of the person and saving energy.

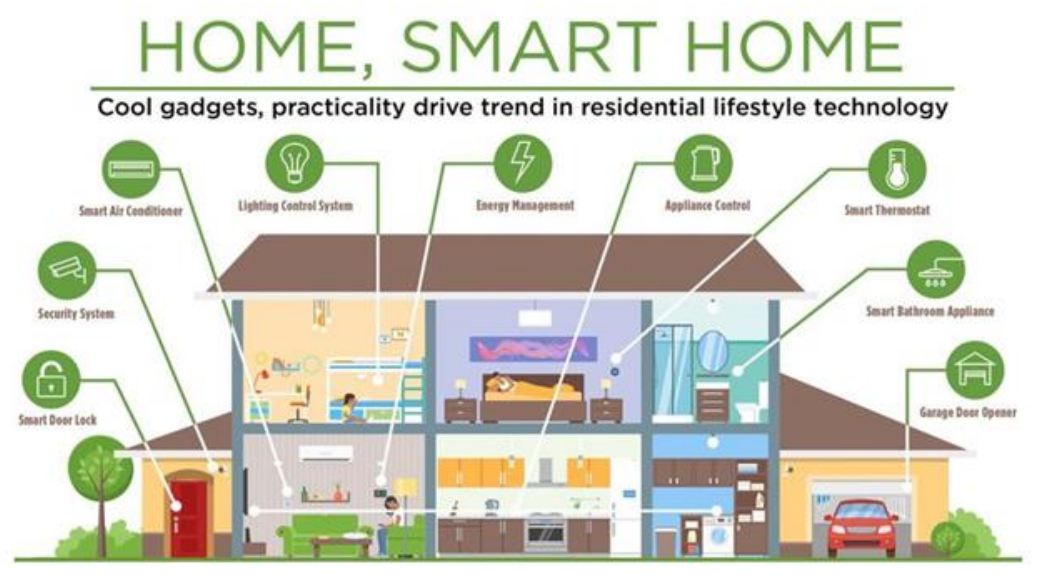

Figure 1. Home Automation Systems

\section{2) Energy and Ecology}

Looking at the past centuries, the way of life of man has changed dramatically. In this context, an architectural approach should be adopted that will not lead to environmental pollution, shortage of resources and deterioration of ecological balance, and should be switched from traditional high consumption mode to low consumption and low pollution mode. Thanks to smart homes, how much electricity each electronic device used at home or in the workplace consumes, no matter where the user is, they can be monitored 
instantly and reports can be examined. Thanks to intelligent control technology, power tools, lighting systems, heating cooling systems can save energy (electricity, natural gas, etc.) without giving up comfort.

With the smart home system, energy consumption values and statistics for the past period can be viewed, analyzed and compared to general averages. Energy consumption used in previous months and data from the relevant month can be compared to the energy consumption of future periods. The smart home can continue to control and manage energy consumption even when it is not at home, and alert information messages can be sent to the user when a consumption above the previously defined average values is detected.

With user-designed configurations and scenarios, the home can be automatically put into outdoor mode, and electronic devices such as televisions can be put into sleep mode to prevent unnecessary energy consumption. Lights or unnecessary working devices that do not need when sleeping can be switched off from a single point, automatized and saved.

\section{3) Safety and Safety}

The smart home system can send informational sms, e-mail, drop calls to phone numbers specified by the user, or create camera recording in accordance with scenarios, depending on the specific scenarios set by the user. With an advanced and remote manageable automation system that is always connected to the central alert system, the security of the house or workplace can be provided more intelligently and more reliably. It protects and takes counter-essentials to all kinds of undesirable situations that are valuable to the user, unauthorized use, theft, fire, flooding, gas leakage and so on. Smart homes provide preventive and protective service, rather than just a warning and alarm system, such as ordinary security systems. Control of your home or workplace from anywhere with smart home systems is under user management.

\section{4) Comfort}

Everything in the smart house can be easily adjusted and very complex scripts can be simply designed. Many commands can be managed with a single click, so all devices are freed from the hassle of checking separately. For example, with a designed "Welcome home" scenario, lighting can be turned on in the desired format, the temperature of the desired room can be defined as desired and the air conditioning of the house can be adjusted, the security module can be automatically passively removed or curtains can be turned on automatically. All this can only be done by pressing a single key, with a pre-designed scenario.

With the smart home, a completely user-specific automation and security solution can be designed. Thanks to the advanced programmer, the house can be thought and managed instead of the user. Thanks to its timer feature, all scenarios and commands that it defines work at the desired time and minute. It automatically opens and closes the curtains at this time, referring to the sunrise and sunset. Make the security system active or passive, and this programmer will make it user-specific can be brought in. Thanks to the graphics interface, rules can be easily defined to the system without difficulty, and home configuration can be added and subtracted.

\section{5) Health}

Smart houses Using various sensors and cameras, it provides the opportunity to be aware of the safety of the person's parents or those who take care of the person $24 / 7$ and intervene when necessary by creating elderly-specific scenarios in the house. In case of emergency, it offers quick response by sending sms, email and phone calls with the emergency button.

\section{6) Technology}

Smartwatches, smart wristbands and smart switches are the technologies we've been accustomed to for a few years. In a world where everything is becoming digital, households are also expected to increase management through smart apps. Relatives of the smart home resident can follow where they come from the smartphone. Geo-fence technology allows you to notify the mobile phone when it is away from home or when it reaches home.

\section{7) Entertainment}

All audio, video and home theater systems in the house can be integrated remotely controlled. A computer or mobile phone can be used for all multimedia devices as a remote control. It can automatically turn on and off media units, turn these audio devices on and off remotely and turn them off as a deterrent for the impression that there is someone in the house against thieves when they are not at home.

\section{8) Flexibility}

The rapid changes that are due to time today have made it necessary for structures to adapt quickly to this change. Achieving this rapid change and harmony depends on the capacity of the structure's flexibility. Flexibility is a design approach with spatial and structural strategies that enable the structure to meet changes in the face of possible changes in the process.

\section{Smart Home Types}

Smart homes are homes that can be controlled by remote control in order of sophistication, programmable homes and scripted homes. These houses can be applied today. There are also smart houses with Artificial Intelligence that have not yet been made, but are still in development. In addition, smart homes can be specially designed according to the user's needs. Depending on technological innovations, smart homes are examined in order of sophistication, and apart from these houses, there are smart houses with the flexibility to be shaped according to their intended use. 


\section{Homes That Can Be Controlled by Remote Control}

It is houses that can work with radio brake, do not have a main control unit, can only be controlled by controller. There is no programming and scenarioing capability. Just like a television controller, curtains, lights or other devices can be controlled.

\section{Programmable Homes}

The time-dependent programming of houses that can be controlled by remote control is added. One or more devices can be programmed with timer relays. They are houses with systems that can be automatically opened and turned off at any time with the watch on it, and when not wanted.

\section{Scenario Smart Homes}

Scenario smart homes cover all the features of programmable houses that can be controlled by remote control and adjustable according to time. In addition, the main controller, i.e. the brain of the smart home system, has modules and sensors. Scenarios are entered into this system. For example, thanks to the CPS tracking feature added to the main controller, air conditioning can be operated when we get close to the house. However, the smart home's main controller needs to be entered in advance with the user interface and various scenarios, and one of these scenarios is subsequently selected. (I'm leaving home, like a movie night script, adjust sleep environment script.)

\section{Smart Homes with Artificial Intelligence}

The term Artificial Intelligence has been used for years. However, the concept he expresses varies with the development of technology. AI is self-fulfilling by looking at the data it has, removing the instructions necessary for the completion of the task. The more data, the greater the success of artificial intelligence. Some things AI can do: Speech recognition, text voice over, language recognition, translation, emotion determination, object detection, relationship detection, document review, text production, summarization, question answering.

Artificial intelligence is divided into three: weak Artificial Intelligence, powerful Artificial Intelligence and super artificial intelligence. Weak Artificial Intelligence is a software specializing in different jobs. All these AI software sits together to create smart home software. Powerful Artificial Intelligence can be defined as a computer that can establish a cause-effect relationship, abstract thinking, and draw conclusions from its experiences, which are as intelligent as human beings in everything called human aide. Superintelligence is defined as artificial intelligence, which is superior to human beings in every subject. (Science Technical)

Nowadays, only weak examples of Artificial Intelligence are seen. However, when the powerful AI is reached, super AI will also be opened up. Super AI will be able to decide that it needs to improve itself even if it is not programmed to develop itself.

In scripted smart homes, smart homes with artificial intelligence have the ability to learn when scenarios are created by humans. It monitors its users at a certain time and extracts analysis of recurring movements and activates the command that is intended to be performed according to the reactions shown by its users. The user does not write the scenario of smart houses with Artificial Intelligence, the smart house itself can be written by learning according to repeated movements. For this reason, it is still working today.

\section{Method}

In the study, extensive literature research and research on smart houses in the world and face-to-face interviews with smart home experts in Turkey have been established. In light of the knowledge, eight main topics covering the characteristics of smart houses have been identified. Headings set by conceptual framework Associated. Thanks to all the data collected by taking care of the collection of a large number of scientific data related to the subject of the study, smart houses were examined by SWOT analysis method.

\section{Evaluation of Findings}

In light of the research findings, SWOT analysis of smart homes was conducted in Table 1. The strengths of smart homes are energy saving, security, comfort, time saving, adding need-specific features, providing the ability to perform health checks from home for people aged and with various physical disabilities. The weaknesses of smart houses are that they can lazide people, control of the house, systemic errors can occur, and the cost of smart homeconstruction can be sold as a smart home.

Opportunities for smart homes, protection of energy sources, security being provided at the highest level, increased interest in technology, partial fact of the house in our dream with technology, control of the house can be done from the phone it is easy to make a financial profit in the long term, to add and remove features according to the need, and to make smart homemaking easy. Threats of smart homes, the proliferation of smart home technology, hackers increasingly have access to private information and manage remote homes, and cheap smart home products that are not certified by the proliferation of smart homes increase. 


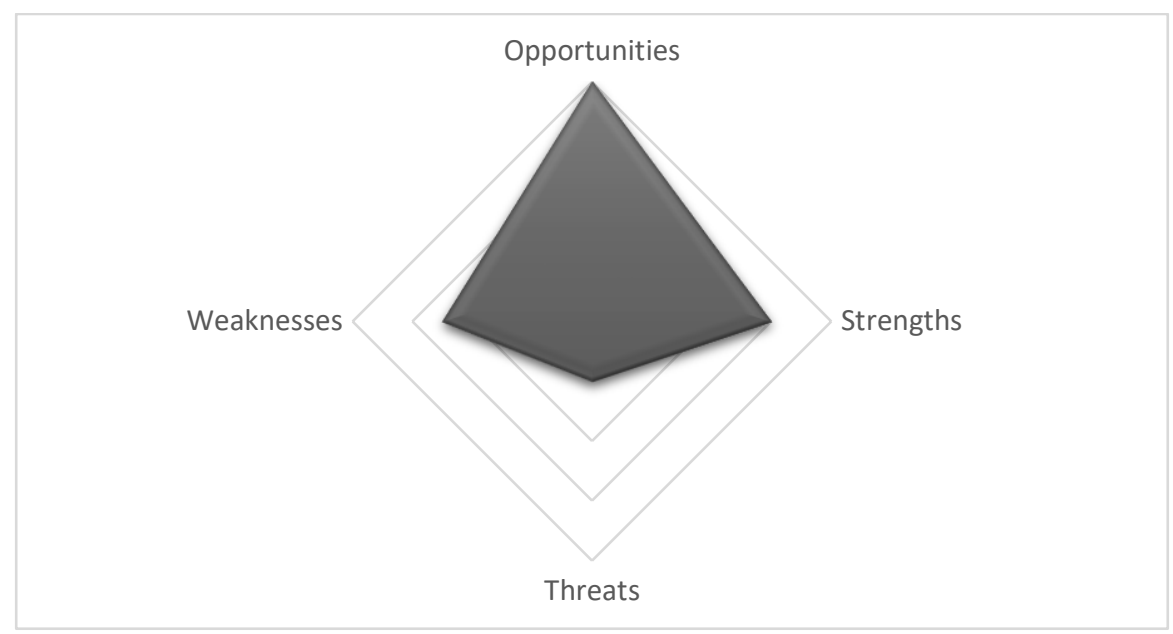

Figure 2. SWOT Analysis

In the Swot analysis of smart homes, the opportunities, weaknesses and strengths, threats, in Table 1, which was created as a result of research, were expressed in Figure 2. When smart homes were evaluated, opportunities and strengths turned out to be more than weaknesses and threats. The opportunities and strengths offered by smart homes make human life easier, maximizing comfort, as well as saving costs of living. It should be minimized by interdisciplinary studies focusing on threats and weaknesses.

Table 1. SWOT Analysis of Smart House

SMART HOME SWOT ANALYSIS

\section{STRENGTHS}

- Saves energy

- Provides security

- Provides comfort

- Saves time

- Need-specific features can be added

For people aged and with various physical disabilities, health checks can be done from home.

\section{OPPORTUNITY}

- Energy sources are protected.

- The maximum level of safety can be achieved.

- Your interest in technology increases.

- The house in our dreams can be partially made a reality with technology.

- Control of the house is easy enough to be done from the phone.

- Makes a financial profit in the long term.

- The property can be added and removed according to the need.

Smart homebuilding is easy.

\section{WEAKNESS}

- It can make you lazy

- Control of the house can be taken

- Systemic errors may occur

- The cost of smart homeconstruction may be high

- Intercom can be sold as a smart home

\section{THREAT}

- Hackers may increase with the proliferation of smart home technology.

-With the proliferation of smart homes, cheap smart home products that are not certified can increase. 
In the Swot analysis of smart homes, the opportunities, weaknesses and strengths, threats, in Table 1, which was created as a result of research, were expressed in Figure 2. When smart homes were evaluated, opportunities and strengths turned out to be more than weaknesses and threats. The opportunities and strengths offered by smart homes make human life easier, maximizing comfort, as well as saving costs of living. It should be minimized by interdisciplinary studies focusing on threats and weaknesses.

\section{Result}

In order to develop technological products, imagination is required as well as the impulse of need. Socio-economic and cultural factors are subjects worth examining in the process of inventing technological products, because socio-economic and cultural constraints also limit the search for technological diversity.

Advanced robot technologies and robot technology bring people to pull their hands off production and heavy work in future times, and many professions are expected to be redefined as part of this situation. Connected devices greatly change our view and behavior to products and objects. The fact that the devices are connected leads to a different relationship between people. The fact that things are connected to the internet in a smart home allows them to connect to a large network, making inter-object communication stronger.

While it is difficult to know where the internet of things entering smart homes will go, in a technology-centric world, more automated homes, using smart tools, shopping in interactive stores, the basic approach to health many different smart systems are expected to be used in the coming years, such as redefining.

The history of technology is filled with optimistic ideas that think of the future as a happier, healthier and rest-oriented place. However, each new technology brings with it a change that is more than positive or negative. For example, the irrigation system, equipped with sensors in smart homes, makes watering easier while saving. Thanks to the internet of things, you can connect to the weather to see if there will be rainfall. Given that this system is connected to the whole city, like smart cities, each system can work more efficiently with the whole city while optimizing conditions by working on its own.

However, if these systems are sabotaged by hackers or terrorists take control of autonomous vehicles, disrupt the traffic network, spies can control devices such as cameras or Google glass to monitor what people are doing and can access confidential data. The internet of things can be used for both good and bad purposes, as it will bring challenges to both our digital lives and security and privacy. Besides, there will be significant changes in social traditions.

As the reliability and efficiency of automated systems is increasing, people rely on automated systems and become indifferent about using their own knowledge and ability. However, the problems that arise from accidents or minor disruptions are greater because it is not foreseen what mistakes these systems can cause.

Technology is not something we are looking for, it should not be the goal that allows us to search, and technology that can't be reached with technology gives us the joy of making time travel searching technology is just a tool around the technology that we are in. to be able to build things

It's impossible to predict what the future will look like. However, the development of technology will make it easier and more difficult in some ways, while increasing safety in some ways, which will improve human quality of life. Another worrying issue is whether the way our mind works when the devices are smart. There are many paradoxes about it. The more work the devices do to our place, the less contact with our natural environment and the less the body and mind work. However, our brains will change to adapt to technology. Time will tell whether human intelligence will increase or remain in the shadow of artificial intelligence.

\section{References}

Akdaş, D., Güneş, H. (2015). Akıllı Evler, İşlevleri ve Akıllı Evlerde Kullanılan Teknolojiler. Bina Elektrik, Elektronik, Mekanik ve Kontrol Sistemleri Dergisi, 166, 128-132.

Asımov, I. (2006). Bilim ve Buluşlar Tarihi. (Çev. Elif Topçugil). Ankara: İmge Kitapevi.

Aslan, A. (2014). Akıllı Ev Kavramı ve Otomasyon Sistemleri. Yüksek Lisans Tezi. İstanbul, Haliç Üniversitesi Fen Bilimleri Enstitüsü İç Mimarlık Ana Bilim Dalı İç Mimarlık Programı.

Bağc1. E. (2018). Endüstri 4.0: Yeni Üretim Tarzını Anlamak. Gümüşhane Üniversitesi Sosyal Bilimler Enstitüsü Elektronik Dergisi. $24,123-146$

Basalla, G. (2013). Teknolojinin Evrimi. (Çev. Cem Soydemir). Ankara: Doğu Batı Yayınları.

Bayram, U. (2006). Akıllı Ev Otomasyonu. Yüksek Lisans Tezi. Çanakkale, Çanakkale Onsekiz Mart Üniversitesi Fen Bilimleri Enstitüsü.

Crofton, I. (2016). Kılçıksız Bilim. (Çev. Dilek Berilgen Cenkciler). İstanbul: Domingo Yayıncıllk.

Doulıgerıs, C. (1993). Intelligent Home Systems, IEEE Communications Electronics Journel. 6, 1291-1297.

Fabı, V. Spıglıantını, G. Corgnat1, S. P. (2017). Insights On Smart Home Concept And Occupants. Interaction With Building Controls Science Direct. 111, 759-769.

Fernandez, J., Losada, D., ve Domonte, E. (2014). An Integrated and Low Cost Home Automation System with Flexible Task Scheduling. $X V$ Workshop of Physical Agents.

Ford, R., Pritonı, M., Sanguinett1, A., Karlın, B. (2017). Categories And Functionality of Smart Home Technology For Energy Management. Building and Environment Journel. 123, 543-554.

Freeman, C. ve Louça, F. (2016). Zaman Akıp Giderken. (Çev. Osman S. Binatlı). İstanbul: İthaki Yayınları. 
Greengard, S. (2017). The Internet of Things. Amerika: The MIT Press Essential Knowlwdge Series.

Gügül, G., N. (2008). Akıllı Ev Sistemleri ve Uygulaması. Yüksek Lisans Tezi. Ankara, Gazi Üniversitesi Fen Bilimleri Enstitüsü.

Gül, F. (2010). Akıllı Ev Sistemleri. Yüksek Lisans Tezi. Ankara, Gazi Üniversitesi Fen Bilimleri Enstitüsü

Işı1klı, Ş. Ve Küçükvardar, M. (2016). Bilişim Devrimi Teknolojinin Felsefesi ve Sosyolojik Analizi. Ankara: Birleşik Yayınevi.

İslamoğlu, Ö. (2018). Mimari Tasarımda Esneklik Yaklaşımlarına Kuramsal Bir Bakış. The Turkish Online Journal of Design Art and Communication. 8, 673-683.

Köksal, A. (2003). Bilişim Toplumu. İstanbul: Toroslu Kitaplığı.

Lütolf, R. (1992). Smart Home Concept And The Integration of Energy Meters Into A Home Based System Switzerland. Landis Gyr Energy Management Corp. Journel. s. 52-61

Lütolf, R. (1992). Smart home concept and the integration of energy meters into a home based system. In Seventh International Conference on Metering Apparatus and Tariffs for Electricity Supply. 277-278. IET.

Mennicken, S., Vermeulen, J., ve Huang, E. (2014). From Today's Augmented Houses to Tomorrow's Smart Homes: New Directions for Home Automation Research. Ubicomp 2014: the ACM International Joint Conference on Pervasive and Ubiquitous Computing. $105-115$.

Osmanlı, U. (2017). Zanaatkârlığın Tarihsel Dönüşümü ve Richard Sennett'in Zanaatkârlık Kavramı Historical Transformation of Craftsmanship and Richard Sennett's Concept of Craftsmanhip. Journal of History Culture and Art Research. 6, 803-817.

Railton, A., R. (1950). Push Button Manor, Popular Mechanics Magazine. 252, 85-87.

Saito, N., Menga, D. (2015). Akıllı Ev Ağlarının Ekolojik Tasarımı. Woodhead Yayıncılık.

Schwab, K. (2016). Dördüncü Sanayi Devrimi. Çev. Zülfi Dicleli. İstanbul: Optimist Yayınları.

Sharr, A. (2013). Mimarlar İçin Heidegger. (Çev. Volkan Atmaca). İstanbul: Yapı Endüstri Merkezi Yayınları.

Tez, Z. (2005). Tekniğin Evrimi. Ankara: Paragraf Yayınları.

Winston, R. (2014). Bilim Tarihi. (Çev. Serhat Atay). İstanbul: Alfa Yayıncılık.

Wilson, G. Pereyda, C. Raghunath, N. Vd. (2019). Robot-Enabled Support of Daily Activities in Smart Home Environments. Cognitive Systems Research. 54, 258-272. 